\title{
From Community College to University: Institutionalization and Neoliberalism in British Columbia and Alberta ${ }^{1}$
}

John S. Levin, Aida Aliyeva, \& Laurencia Walker

University of California, Riverside

\begin{abstract}
This qualitative investigation of higher education institutional development addresses new universities that were former community colleges in the provinces of British Columbia and Alberta. Stemming from an original study conducted nearly two decades earlier, this investigation's data were collected from the same institutions and from similar sources: institutional documents, government policies, and interviews from faculty and administrators; thus, qualifying as a longitudinal qualitative investigation. This investigation explains institutional instability and identity change as a result of new government policies and institutional norms during the period of 2000-2013. Future research can monitor the influence of neoliberal practices on the development of these new model higher education institutions in the Canadian context.
\end{abstract}

\section{Résumé}

Cette étude qualitative sur l'expansion des institutions d'enseignement supérieur porte sur l'étude de nouvelles universités qui étaient autrefois des collèges communautaires des provinces de la Colombie-Britannique et de l'Alberta. Issues d'une enquête menée il y a environ deux décennies, les données de cette étude ont été recueillies auprès de ces mêmes institutions et s'appuient sur des sources similaires : documents institutionnels, politiques gouvernementales et entretiens avec le corps professoral et les administrateurs, donnant ainsi un caractère longitudinal à l'étude. Celle-ci explique l'instabilité de ces institutions et leur changement d'identité, conséquences de nouvelles directives gouvernementales et de normes 
institutionnelles des années 2000à 2013. Defutures recherches pourront suivre l'influence des pratiques néolibérales sur le développement de ces nouvelles institutions d'enseignement supérieur dans un contexte canadien.

In 2008 and 2009, the provincial governments of British Columbia, first, and Alberta, second, established new model universities out of community colleges. These actions not only signalled a culmination of the development of specific community colleges in both provinces since the late 1960 s and early 1970 s but also moved institutions culturally associated with egalitarianism and social service (Dennison \& Gallagher, 1986) both to congruency with neoliberal practices of the state and to a new institutional identity. Although Morphew (2002) in the US context notes that the change from "college" to "university" can be explained by three motivations or determinants-legitimacy, resource acquisition, and curricular change-he neglects the role of government and politics in actions directed at public colleges. In the establishment of these new model universities, the governments of Alberta and British Columbia ensured that these institutions, former community colleges, would not be granted the level of autonomy of traditional universities in Canada (Dennison, 2006). Indeed, these new model universities, while combining characteristics of community colleges and traditional universities, maintained their alignment with provincial governments' market liberalism or neoliberalism (Quiggin, 2010).

Through the process of globalization, the ideology of neoliberalism has touched down in institutions throughout the world, including postsecondary institutions (Seddon, Ozga, \& Levin, 2013). This ideology surfaces through policies at several levels-national, state/provincial, and local/institutional. Scholars argue that neoliberalism has touched nearly every facet of higher education at the institutional level (Ball, 2012; Deem, 1998; Gould, 2003; Marginson \& Considine, 2000; Pusser, Kempner, Marginson, \& Ordorika, 2011). Quiggin (2010) underscores that the outcomes of neoliberalism (or what he refers to as "market liberalism") lead to inequality, and thus the state, in supporting market liberalism, abrogates its role in supporting the public good and fostering social democracy, affecting important elements of educational values and purposes. These values and purposes, suggesting service to communities and ultimately enhancing social mobility and further educational and employment opportunities for populations, especially underserved populations, are at the core of the community college (Dennison \& Gallagher, 1986; Levin, 2002).

Neoliberal ideology in higher education can be traced back to the 1980s, and its effects were documented from the late 1990s, particularly for universities, to the middle part of the first decade of the 21st century (Deem, 1998; Gould, 2003; Levin, 2001; Marginson \& Considine, 2000; Powles \& Anderson, 1996; Pusser, 2008; Slaughter \& Leslie, 1997; Slaughter \& Rhoades, 2004; Stromquist, 2002). Almost without exception, scholarly views pronounced neoliberalism to be a pernicious ideology in its effects upon education. Indeed, neoliberalism is used almost invariably as a negatively charged term, connoting an ideology that is personally selfish, economically grounded, and competitively akin to survival of the fittest. Less noted in earlier scholarship are the ways in which neoliberalism has placed new and stressful responsibilities upon academic professionals, for example in performance expectations (e.g., efficiency, productivity, and generation of resources or public recognition), to increase the competitiveness of their organizations (Ball, 2012). 
Such competitive behaviours are evident both within institutions and between institutions (Pusser et al., 2011; Slaughter \& Leslie, 1997).

As some community colleges in Canada migrate to this new model university status, as they have in Alberta and British Columbia, they may lose their foundational principles (Levin \& Dennison, 1989), become more connected to global economic preferences and orientations (Levin, 2002), and adopt not only university structures and missions but also characteristics of the neoliberal university (Slaughter \& Rhoades, 2000). Community colleges have been tagged with the label "neoliberal" or have exhibited characteristics of the neoliberal state (Levin, 2007; McKay, 2014), yet neoliberal colleges are distinct from neoliberal universities, given the institutional characteristics of a university. These distinctive characteristics include judgments based upon merit, academic freedom, and selectivity. "Canadian universities ... place a strong emphasis on academic and institutional autonomy, selectivity in student admissions, a curriculum planned on a largely theoretical basis, participatory governance in a bicameral format, and their role as critics of conventional wisdom" (Dennison, 2006, p. 108).

The present investigation was designed to determine whether new model universities in British Columbia and Alberta have adopted and embraced neoliberal practices, and, if so, to what extent. This investigation addressed not cause and effect but rather institutional changes and their association with practices that are aligned with neoliberal values. Specifically, this investigation addressed institutional change to those community colleges in Canada that developed into new model universities from 2000 to 2013.

\section{Institutionalism as a Way to View the Community College}

Institutional theory provides several avenues to approach, examine, and understand institutions of higher education. Institutionalism suggests boundaries separating one entity from another based upon certain characteristics such as purpose and goals, values, history, legal formation and operations, and norms, rules, and regulations (Scott, 2014). One scholarly view of community colleges (Levin, 2001) has characterized and defined the community college as occupying its own institutional field, one that is considerably different from those of universities, four-year colleges, and high schools. Community colleges in Canada contain, articulate, and enact common features that set them apart from other educational institutions that might reasonably be assumed to share an institutional field or be understood as the same or the same kind of institution (Dennison \& Gallagher, 1986; Levin, 2002; Levin \& Dennison, 1989). Several historical (that is, from the 1960 s to the present) features have guided the development of community colleges, features that set them off from other entities (Levin, 2001). These include open access, comprehensive curriculum, and community responsiveness, among others.

These features not only identify the community college as an institution unlike others but also shape and influence the community college, leading to considerable commonality among these institutions. What are referred to as "taken-for-granted assumptions" in institutional theory (Colyvas \& Powell, 2006) apply to behaviours and actions at individual community colleges based upon not only individual college history but also institutional norms and expectations of the community college. For example, whether the community college is located in Cranbrook, British Columbia, or Red Deer, Alberta, organizational members, such as faculty and administrators, not only understand their college's respon- 
sibility to provide remedial course work and student support services for a population of their students who struggle with the English language or mathematics but also have little need to debate or even discuss this responsibility. These organizational members do not question this responsibility but rather assume it is a given part of their institution's mandate. These understandings and agreements make up the institutional logic of the community college (Thornton, Ocasio, \& Lounsbury, 2012).

These institutionalized views and practices provide stability for the community college. Yet, in the face of new policies and initiatives, when community colleges migrate to university status, core views and practices are challenged. New policies and initiatives can become rationalized and then institutionalized, or they can be dismissed (Thornton et al., 2012). During this process, there is potential for considerable institutional instability, and for tensions and conflicts among institutional members, because the institutional assumptions common to universities can differ from those in community colleges. Thus, for those community colleges that transition to university status, there are expectations for faculty to conduct research and assumptions about professional rank (e.g., assistant professor, associate professor, and professor), tenure, and the provision of bicameral governance. All of these behaviours and conditions are legitimate in universities and thus these practices are unquestioned. But these practices are not necessarily compatible with community colleges and do not conform to the institutional logic of the community college.

\section{Research Questions}

Two main research questions guided this investigation: What are the major structural and mission changes among community colleges that developed into universities from 2000 to 2013? To what extent do these changes reflect neoliberal practices?

\section{Research Design and Methodology}

To address these research questions, the methodology employed was qualitative field methods research (Burgess, 1984; Erickson, 1986; Maxwell, 2005), with reliance not only upon qualitative data collection methods and data analysis but also upon the researcher as the instrument (Maxwell, 2005). This investigation utilized data that address the 2000-2013 period, and it reflected upon findings from an earlier and informing study from 1989 to 1999 (Levin, 2001). Thus, this investigation falls under the category of longitudinal qualitative research (Holland, Thomson, \& Henderson, 2006). This project returned to original findings and sites from the earlier 1989-1999 study to determine policy outcomes, particularly in the form of institutionalization of policies and practices from 2000 to 2013. The sites are three institutions in British Columbia and Alberta. The institutions were given pseudonyms, to match the names of the previous investigation, and as required by the institutional review board of the researchers' university. The pseudonyms are East Shoreline University (ESU), in British Columbia; Rural Valley University (RVU), in British Columbia; and North Mountain University (NMU), in Alberta.

There were several major steps and strategies in this investigation. The first step was the collection and review of 2000-2013 documents at individual institutional and national and provincial policy levels to determine both policy priorities and initiatives during this period for institutions. The second step included meetings and engagement with 
practitioners, involving faculty and administrators at the three institutions to solicit their views on the major questions of this research. Interviews are efforts to capture participants' perceptions and their understandings of institutional behaviours in their words (Erickson, 1986). The principal researcher visited the three institutions during September and October 2013 and interviewed 27 institutional members for one to one and a half hours each. Of those interviewed, 8 (or close to 30\%) had also been interviewed during the previous investigation, in 1997 and 1998. As well as interviews, the principal researcher recorded observations of campus visits and interactions with campus officials in a journal. This form of ethnographic data collection (Berg, 2001) constitutes efforts to record observations in the field. The journal was also a recording of the researcher's reflections upon interviews and observations of the sites, including preconceived notions, reflections upon interactions, and the connection of observations to theory.

The third step entailed the analysis of data by a team of researchers. One stage of this analysis involved document analysis. The other and major stage was interview data analysis in order to address the research questions (Miles, Huberman, \& Saldaña, 2014; Richards, 2009). Documents from 2000-2013 on government, non-government, and institutional priorities for the three institutions were coded, as were interviews conducted in 2013. The documents included annual reports; board of governors' meeting minutes; collective agreements; academic, strategic, and institutional plans; policies; and procedures. A coding scheme based on qualitative data analysis techniques suggested by Bogdan and Biklen (1992) was developed using concepts drawn from literature on neoliberalism. Codes included the following: competition (C); individual benefits (IB); privatization (P); free or liberal market (FM); reduced social expectations (RS); reduced government responsibility (RG); dismantling or eroding of social welfare (DW); and individual economic worth (IW).

In addition to data coding, thematic categories organized interview data to address the research questions. For the first research question ("What are the major structural and mission changes among community colleges that developed into universities from 2000 to 2013?”), interview data were categorized topically or thematically and then analytically (Richards, 2009), based upon institutional theory (e.g., the importance of institutional history and culture, institutional boundaries or fields, institutional isomorphism). On the one hand, data were categorized on the basis of the historical mission of the community college (e.g., access to education and training, comprehensive curriculum, student-centredness, job preparation, university transfer, community education). On the other hand, data were categorized based upon the structural changes (e.g., in curriculum, financing, governance, and leadership) noted by institutional participants. We followed qualitative scholarship on systematic data analysis (Miles et al., 2014) in order to generate findings and conclusions from the field research. This included the identification of variables (e.g., institutional leadership), explanation of causal chains (e.g., the Great Recession), the noting of patterns (e.g., accountability behaviours), the making of conceptual coherence (e.g., legitimization), and the capturing and use of metaphors (e.g., academic "wannabes").

Subsequently, findings derived from the first research question were linked to neoliberalism by data outcomes from the second research question ("To what extent do these changes reflect neoliberal practices?”). Data were categorized analytically (Richards, 2009) using tenets of neoliberalism drawn from the scholarly literature. The categories 
captured ideological commitments to competition; economically directed behaviours, especially those directed toward global markets; reduction of government responsibility for social needs; and the political privileging of those with the greatest capabilities and advantages. Although differences in the findings for each of the three institutions were identified, for this investigation the goal was to identify and explain common attributes and behaviours. However, in the final section of this article, several differences are noted and point in a direction for further research.

\section{Findings}

On the institutional level of the former community colleges that are now new model universities, this research shows whether missions and structures have altered as a consequence of government policy and, if so, to what extent. Second, the research documents behaviours and actions that both shape and characterize each institution in such areas as faculty work and curriculum, as well as behaviours and actions that pit community college values and practices against university values and practices. Finally, this research explains the effects of government policies on the institutions in such areas as governance and finance.

\section{Missions and Structures: University Status in British Columbia and Alberta}

In 2008, two community colleges, here called East Shoreline College and Rural Valley College, were designated East Shoreline University and Rural Valley University by the British Columbia government (British Columbia, 2013b); in 2009, the pseudonymous North Mountain College was designated North Mountain University by the Alberta government (Alberta, 2013). Their new formal status as universities led to altered structures and challenged the historical mission of these institutions. This new status contributed to what one of the new universities' department chairpersons referred to as an "identity crisis" for her institution, in that with both community college origins and now university status the institution had "multiple identities." In addition, role expectations for faculty had undergone considerable change. A faculty member with a senate leadership role noted that all full-time faculty were expected to "conduct high-level research," even though their institution was designated a teaching university, with a workload in teaching comparable to the load they had had when the institution was a community college. "Everyone who's hired now has to have a research component to their position" (Faculty, NMU). The new status of these institutions came with new responsibilities: The research component along with the teaching component was a major aspect of faculty's position requirements.

Articulated in the British Columbia University Act, the role and responsibilities of faculty were nested within a body called "the faculty," with each institution made up of "faculties." "The faculties of each university may be constituted by the board, on the recommendation of the senate" (British Columbia, 2013b, section 39.1). Thus, for former community college faculty, their roles and responsibilities moved from the traditional community college role of instructor, defined in a collective bargaining agreement (British Columbia, 2013a), to a more elevated professional role, in the form of a professional body. This body for faculty-distinct from the faculty designation in the act that governed them when they were community college faculty and that denied them authority as a 
group except through collective bargaining (British Columbia, 2013a)-had considerable authority in the governance and management of the institution. This body's roles included self-governance: "to make rules for the government, direction and management of the faculty and its affairs and business" (British Columbia, 2013b, section 40[c]). There was a similar change of roles for former community college faculty in Alberta, applicable to North Mountain University as of 2009 (Alberta, 2013), although a faculty council rather than "the faculty" was the professional body.

These legislative changes in British Columbia and Alberta resulted in professional identity alteration: Faculty, once referred to as "instructors," either were referred to as or were considering such labels as assistant professor, associate professor, and professor. They also led to adoption or consideration of the adoption of tenure; reliance upon a senate body for bicameral governance; and justification of research as a significant component of the workload. For example, a faculty member who served as an executive member of the senate at RVU explained the period of transition, in this case the institutionalization of academic rank.

The collective agreement changes status and then there is a period of time for those existing faculty who qualify for grandfathering, which will be the vast majority of the existing faculty. I think we'll all be in the associate professorship status and it goes from there. (Faculty, RVU)

The change was similar at ESU, where a mid-level administrator noted the transitions: "Well, I guess we were instructors when we began; we became professors at some point in that process." Institutional reports also documented the establishment of academic rank; a 2007 NMU report noted the use of "the traditional titles of Instructor, Assistant, Associate and Full Professor but with somewhat less traditional expectations of performance within rank." These alterations in titles and professional responsibilities as well as role expectations were consistent with the mission alteration that emphasized higher-level postsecondary education (e.g., the baccalaureate degree). "Now the institution and the academic leaders of the institution accept that research and scholarship are good things" (Faculty, ESU). The new status of the institutions not only came with new additional responsibilities for faculty, such as engagement in research; it also created incentives of prestige maximization and increased reputation for academic leadership, as "research is so valuable to the prestige of the institutions" and the advancement of their reputations (Goldman, Goldman, Gates, Brewer, \& Brewer, 2004, p. 31). Higher prestige, expanded role responsibilities, and academic rank stratification for faculty combined with broadening of mission and new governance structures for the institutions were the result of the formal designation as universities.

\section{Behaviours and Actions}

While the new model university status can be viewed as means for increasing prestige for these institutions, faculty and administrators noted that their transition to university status required substantial organizational and institutional alterations. These included changes to curriculum (e.g., degree programs at the baccalaureate level and in British Columbia at the master's level) and to the composition of institutional bodies (e.g., senates). These alterations influenced the behaviours and actions of institutional members. 
When faculty were charged with establishing a departmental identity in the form of goals at the local (departmental) level, they found that they were to behave and act in a manner that was dictated by the administration; in other words, "department goals became institutional goals" (Faculty, RVU). Yet at times the larger institutional goals (i.e., indigenization of the curriculum) proved to be a challenge for some departments: for example, determining course offerings and the types of students they were now required to serve. This bred a critique of the administrative structure and of the influence of administrators, now heavier than in the past.

The administrative structure is thick. Once we became a university, the administration grew in number of vice presidents, deans, and associate deans. These people generate their own interests and there are now many layers. The new senate is in its early days and it is more in line with the administration. (Faculty, RVU)

At NMU, a faculty member's perspective reflected not only the alterations through institutionalization of university status but also a longitudinal perspective of 30 years: "The switch to university status is a big one." The view just prior to 2009 suggested that the alteration would not necessarily make the new universities congruent with the traditional universities in the province. A 2007 report leading up to the college's transition notes that as a university North Mountain would be distinctive: "The principles of primacy of teaching and equivalence of scholarly activities have the potential to make the institution appear markedly different from most universities: this can be both an advantage and a vulnerability." As new university status for NMU became imminent, the well-established provincial universities acted in a manner that viewed NMU as a competitor. "They [other universities' administrative leaders] did say that they had some concerns about too many pigs at the trough, I think was one of the expressions that was floated around" (Faculty, NMU). Although NMU had collaborated previously with another university to offer a fouryear degree, NMU's new university status required that it alter its curriculum significantly and subsequently gain approval for degree programs from the provincial government, a change from when North Mountain was a community college. This entailed the cutting of some programs. "We cut some less relevant programs, a transfer program, a music performance diploma, and this is where you'll see some changes ... [in] the diplomas, certificates and university transfers, rather than degrees" (Senior administrator, NMU). As well, NMU endeavoured to satisfy the provincial government in its curriculum. "Right at the moment we're trying to reposition ourselves in terms of degree offerings. A number of the old applied degree programs and a number of the university transfer programs are being ... put forward to the ministry as proposals for our degrees" (Associate dean, NMU). The alterations in behaviours and actions, both those formally required of and by the institution and those informally carried out by faculty, led faculty to reflect and view the past nostalgically during their community college period: "It was nice before we were so big."

For ESU, during its period as a community college, there was internal competition over resources and prestige between two main program areas: the trades and the academic or university transfer program. However, with its new university status, ESU witnessed the culmination of competition not just between trades and academic programs but also within the academic programs, leading to a condition akin to survival of the fittest. 
I think the trades believe that they have lost to the academy.... But even within the academy you have these feelings that the sciences lost to the humanities. ... Now there's very much an anxiety around: "Oh, if you had enough money you could let business grow up the wazoo and shut down some of the humanities disciplines." So there's always a kind of a tension or a hierarchy, I think, going on. (Senior administrator, ESU)

As well, administrators were aware of the competition they faced from other four-year institutions. At ESU, administrators took proactive roles, planning strategically with consideration of the market viability of baccalaureate degrees. Yet the market was not a free market.

We tried to take a more strategic approach and said, "Okay, we're going to develop a three-year plan of new degree activity." And so we did all that. And then the government reversed direction on the funding. So we really got kind of screwed [by the government]. (Senior administrator, ESU)

ESU was, in essence, financially penalized for not acting fast enough to meet governmental expectations. Such actions (i.e., reduction of government funding due to perceived inefficiency) created additional stressors during the institution's transition to university status. Institutions had been under pressure to innovate in order to compete, whether "through blended learning models using distance learning technology" or by the development of "a collaborative model for regional field station operations that attracts educational, not-for-profit, industry and government partners and maximizes funding opportunities for shared funding of operational costs," as ESU's 2012 action plan noted.

\section{Government Policies and Their Neoliberal Tendency}

For the colleges that transitioned to "new model universities" in British Columbia and Alberta, referred to as "special purpose, teaching university" in British Columbia and included under the designation of "Baccalaureate and Applied Studies Institutions" in Alberta, government legislation ensured that they would not have the same autonomy from the province as the "traditional universities." The government controlled the funding and intruded "on the autonomy of the institution" (Senior administrator, ESU). For example, a business faculty member from RVU connected new model universities to the economic interests of the provincial government.

I think the big issue is ... how legislation is set up as a special-purpose teaching university. Bottom line, it's the economy. . . . There's no line of autonomy and the board members, the majority of them, are effectively picked by the provincial government. ... I don't think ... board members that come in here are going to be kicking up a lot of criticism of the government. ... The newer model [of universities] . . is not really set up to take positions; they're very much creatures of government. (Faculty, RVU)

In both provinces, enshrined in legislation was language that separated one kind of university from another: One was teaching-oriented and the other was focused upon research as a major function; one was tied through policy to the provincial government and 
the other was relatively autonomous from the provincial government. This terminology was reflected in university documents such as budget recommendations, academic and institutional plans, and collective agreements. The new model universities contained senates, which their predecessor community colleges did not have before 2008 in British Columbia and 2009 in Alberta. In British Columbia, enabling legislation that created the new model universities curtailed the powers of the new model universities' senate compared with those of the "traditional university." British Columbia's University Act deals with the powers of the special-purpose teaching universities' senates and provides that the senate "must advise the board, and the board must seek advice from the senate, on the development of educational policy" (British Columbia, 2013b, section 35.2 [6]). No such requirement appears in the legislation for the traditional universities. At both institutional types, over $50 \%$ of board members are appointed by the provincial government, thus ensuring at least a formal connection of governance to the state and, in the case of the new model universities, an accountability measure on educational policy (McGillivray, 2012). Furthermore, both governments "were very careful, with the special-purpose teaching universities, not to make them look like research-intensive universities. So [the emphasis is on] applied research within the limits of [the institution's] own budgetary abilities, and no special funding for that" (Dean, ESU). In British Columbia in particular, the government enshrined faculty roles in legislation, as noted above (McGillivray, 2012).

One of [our] features . . . as a special-purpose university . . . is that we have a mandate for applied research. ... No one can define what applied research is and the act does not define it. The government is insistent on it and it is a meaningless distinction, particularly meaningless in the various jurisdictions in humanities and social sciences, and science and technology, the liberal arts and sciences here. (Faculty, ESU)

Curtailment of institutional autonomy, combined with practices that treated the new universities as extensions of provincial policy, and economic policy in particular, undermined the traditionally understood public university identity in Canada.

One thing has remained fairly consistent since 1989 , and that is that irrespective of actual policies, government has been sharply inclined to micromanage this sector. So its approach to the big three or four [universities] in this province is hands off, and its approach to ESU is hands on. And that's irrespective of policy. Policy may say it's hands off, but it's hands on.... That has been, at an operational level, one of the great struggles of this university and of its evolution as a university college and now as a university. (Humanities faculty, ESU)

For the new model universities in British Columbia and Alberta, one way to interpret government actions is to view these as responding to the provincial governments' higherlevel education and training needs through the production of baccalaureate graduates who will benefit the economy, rather than responding to lower-level postsecondary participants who provide relatively less provincial economic benefit-a large component of community colleges' student body-and supporting liberal education. 
The government seems to really be concerned with skill shortages and trades. . . Education relates to the employment market more than ever, and I don't think that was a factor 15 years ago. Now they have learning outcomes and outcomes include employability. . . . Business has a high level of employability and we are really training people to be accountants and marketers ... more so than teaching them about Shakespeare. (Faculty, RVU)

Furthermore, in establishing new model universities, the provincial governments retained their influence through funding priorities, ensuring that new programs were oriented toward employment and not imitating the "esoteric" degree programs of more traditional universities. "We're now saying, 'It's got to be employment; will this person get a job?' Well, now that's the criteria” (Faculty, RVU). Thus, in order to establish new programs, these new universities were expected to change existing programs, or drop these programs and replace them with new degree programs. To satisfy the provincial government, in order to continue to secure funding from government, those programs had to be in areas that led to employment, even if they were more educationally advanced programs than those customarily offered at community colleges. That meant either heavy emphasis on job training specifically or the development of bachelor's and even master's degrees, which were preparations for employment. Thus, traditional vocational programs either were structured to ladder to degree programs or became degree programs. "Some of the tech programs, like the resource management officer training program, [continue as] a two-year program. . . . But they've also expanded it. . . They've made laddering opportunities.... There's now a degree program in that" (Mid-level administrator, ESU).

Counter to the expectations that university status brings autonomy to former community colleges, these new universities' dependence upon the provincial government for funding and policy (e.g., tuition policy) tied them to government priorities while they endeavoured to develop as universities. That is, they were expected to be liberal market institutions, responsive to the economic marketplace, trying to juggle expectations both as neoliberal community colleges and as neoliberal universities.

The labour market was not the only economic concern for the governments of British Columbia and Alberta. Cost containment of the public sector was also a priority, acknowledged at ESU as accountability of the institution to the provincial government with high levels of financial oversight.

So the accountability measures that's been so key a feature of the Liberal government [for] more than a decade . . . they've now extended . . . into the sphere of accountancy.... But a lot of the accountability stuff, it's what you're familiar with in the States. And it's hitting here. ... One of the consequences of those accountability measures has been very rigorous accountancy changes that have made it very difficult for [us]. . . . It comes back to ... being micromanaged by government. (Faculty, ESU)

Even if these institutions could serve additional students, the provincial governments refused to expend their resources for student access to further education. "We can support more students here; the government just won't fund them.... We have the capacity, but they are not willing to fund the students" (Faculty, NMU). New institutions that were 
accustomed to a mission of open access faced financial constraints and changing government regulations, which did not allow these institutions to continue to support the open access mission. Thus, new universities were doubly challenged. Their aim to continue with community college principles of community responsiveness, to focus upon teaching (rather than research), to provide broad access (Dennison \& Gallagher, 1986; Levin, 2001), and to develop into a traditional university identity was, on the one hand, not fully compatible with government policy and, on the other hand, arrested by it.

\section{Conclusions}

The establishment of new model universities that were developed from former community colleges was a process deeply embedded in institutional contexts, as well as in the legal, social, economic, political, and historical contexts. In the case of these three institutions, provincial government policies and actions were clear shapers of institutional development and change, primarily through policy and funding preferences. Numerous policies of the provinces were consistent with neoliberal ideology; neoliberalism favours the economic marketplace and largely unfettered competition for optimal outcomes so that institutions such as colleges and universities are expected to behave like business corporations and faculty are pressured to conform to commercial criteria (Crouch, 2011). Where there are practices that are antithetical to neoliberalism, such as the access mission of community colleges or ethical and normative standards of the academic profession, then there is potential for conflict and stress in institutional behaviours.

What altered in higher education institutions, based upon the experiences of these three institutions, was either the tightening of government influence or the press of neoliberal ideology and policy, or both, with government using funding as a lever of change. On the one hand and to some degree, the new model universities had a symbolic identity and legal status as academic institutions, with more emphasis upon the expertise of their core operators than community colleges. Yet the provincial governments as the primary funders had the ability to control operations and shape behaviours through resource allocations, both in quantity and in type of allocation (i.e., allocations were designated for specific uses). In the Great Recession of 2008 (Rampell, 2009), which resulted in government cuts for subsequent years, the return of pre-2009 level funding for all higher-education sectors was largely targeted to government priorities, such as curriculum that was aligned with employment potentials in business and industry and instruction that led to measurable student outcomes. Government coveted ends that were economic and that supported both the economy and any means that were efficient and simple to demonstrate.

What is perhaps as significant here as government behaviours was institutional behaviours, particularly those of faculty and administrators, which reflected the integration of neoliberal preferences and policies into professional work. Consistent with institutional theory, organizational members constructed and agreed upon meanings of actions or institutional logics (Thornton et al., 2012) that provided a framework for social actors to make sense of or accept institutional behaviours and actions. The institutional logic of the community college is not the same as the logic of the university. In British Columbia and Alberta, administrators and faculty embraced government actions in the creation of universities out of community colleges, on the one hand pushing institutional policies forward to have their institutions' identity resemble those of universities: policies on 
faculty titles, tenure, bicameral governance, and research and workload. On the other hand, these actions reveal the values of their institutions' origins as community colleges and their rootedness in non-elite status as a reflection of their democratic goals (Dennison \& Gallagher, 1986). Alignment of provincial government goals and interests-largely economic, with preferences for diminished social provisions and for increased marketization-and new universities' practices was achieved, and these institutions may be considered extensions of a neoliberal state (Ball, 2012).

Although colleges in British Columbia and Alberta share a common developmental past-in large part, they were modelled after California community colleges (Dennison \& Gallagher, 1986) - their political jurisdictions and their politics, as well as their economies, arguably, have shaped them to the present. A number of factors in British Columbia-the salient role of the faculty union (Levin, 2001); the university college idea and functioning (Dennison, 2006), which connected the two former community colleges as university colleges to the major provincial universities (Levin, 2002); and a political economy based upon natural resources, subject to boom and bust and to polarized provincial politics, with the left (or, more recently, since 2000 the Green Party and environmentalists) opposing a large portion of the government's agenda and policies (Barman, 2007)-distinguished British Columbia from Alberta during the 2000-2013 period. The two British Columbia universities-Rural Valley University and East Shoreline University-exhibit some differences, in some respects, as a result of administrative leadership. Yet they are highly similar in their development as new universities (e.g., establishing master's degree programs and maintaining adult basic education programming). The Alberta university, North Mountain University, has held steadfastly to undergraduate education only, with no intent to offer graduate degrees; its administrators and faculty claim that excellence in teaching is their niche. Yet North Mountain moved quickly to selective admissions and the denial of admissions to thousands of potential students, a behaviour not evident at either RVU or ESU.

More pertinent to this investigation, however, is that all three new universities have adopted numerous characteristics of traditional universities: a focus upon research, academic rank, tenure, and bicameral governance, as well as the devotion of the preponderance of resources and planning to baccalaureate programming. Future investigations could follow this development to ascertain whether these institutions wholly adopt the logic of universities and shed the logic of the community college. Furthermore, future research can monitor the institutions' adoption of neoliberal practices, which might entail growing privatization (e.g., higher tuition and low provincial government financial support), competition with other institutions for resources (e.g., private donors), internal competition (e.g., financial responsibility centres), and market-oriented performance measures (e.g., graduation rates and student learning outcomes).

\section{Note}

1. For John D. Dennison 


\section{References}

Alberta. (2013). Post-secondary Learning Act. Statutes of Alberta, 2003, chapter P-19.5. Current as of June 12, 2013. Retrieved from http://eae.alberta.ca/ministry/ legislation/psla.aspx

Ball, S. (2012). Global Education Inc.: New policy networks and the neo-liberal imaginary. New York, NY: Routledge.

Barman, J. (2007). The west beyond the west: A history of British Columbia. Toronto, ON: University of Toronto Press.

Berg, B. (2001). Qualitative research methods for the social sciences. Boston, MA: Allyn and Bacon.

Bogdan, R. C., \& Biklen, S. K. (1992). Qualitative research in education: An introduction to theory and methods. Needham Heights, MA: Allyn and Bacon.

British Columbia. (2013a). College and Institute Act. Revised Statutes of British Columbia, 1996, chapter 52. Revised to March 2013. Retrieved from http://www.bclaws. ca/civix/document/id/complete/statreg/96052_01

British Columbia. (2013b). University Act. Revised Statutes of British Columbia, 1996, chapter 468. Revised to March 2013. Retrieved from http://www.bclaws.ca/Recon/ document/ID/freeside/oo_96468_01

Burgess, R. (1984). In the field: An introduction to field research. Boston, MA: George Allen and Unwin.

Colyvas, J., \& Powell, W. (2006). Roads to institutionalization: The remaking of boundaries between public and private science. Research in Organizational Behavior, 27, 305-353.

Crouch, C. (2011). The strange non-death of neoliberalism. Malden, MA: Polity Press.

Deem, R. (1998). 'New managerialism' and higher education: The management of performances and cultures in universities in the United Kingdom. International Studies in Sociology of Education, 8(1), 47-70.

Dennison, J. D. (2006). From community college to university: A personal commentary on the evolution of an institution. Canadian Journal of Higher Education, 36(2), 107124 .

Dennison, J., \& Gallagher, P. (1986). Canada's community colleges. Vancouver, BC: University of British Columbia Press.

Erickson, F. (1986). Qualitative methods in research on teaching. In M. C. Wittrock (Ed.), Handbook of research on teaching (pp. 119-161). New York, NY: Macmillan.

Goldman, C. A., Goldman, C., Gates, S. M., Brewer, A., \& Brewer, D. J. (2004). In Pursuit of prestige: Strategy and competition in U.S. higher education. New Brunswick, NJ: Transaction Publishers.

Gould, E. (2003). The university in a corporate culture. New Haven, CT: Yale University Press. 
Holland, J., Thomson, R., \& Henderson, S. (2006). Qualitative longitudinal research: A discussion paper. London, UK: Families \& Social Capital ESRC Research Group.

Levin, J. S. (2001). Globalizing the community college: Strategies for change in the twenty-first century. New York, NY: Palgrave.

Levin, J. S. (2002). In education and work: The globalized community college. Canadian Journal of Higher Education, 32(2), 47-78.

Levin, J. S. (2007). Neo-liberal policies and community college faculty work. In John Smart \& William Tierney (Eds.), Handbook of Higher Education (pp. 451-496). Norwell, MA: Kluwer Academic Publishers.

Levin, J. S. (2013). Understandings of community colleges in need of resuscitation: The case of community college faculty. In J. S. Levin \& S. T. Kater (Eds.), Understanding community colleges (pp. 233-253). New York, NY: Routledge.

Levin, J. S., \& Dennison, J. D. (1989). Responsiveness and renewal in Canada's community colleges: A study of change in organizations. Canadian Journal of Higher Education, 19(2), 41-57.

Marginson, S., \& Considine, M. (2000). The enterprise university: Power, governance and reinvention in Australia. New York, NY: Cambridge University Press.

Maxwell, J. A. (2005). Qualitative research design: An interactive approach. Thousand Oaks, CA: Sage Publications.

McGillivray, J. M. (2012). Reclaiming the public through the establishment of a senate in a nascent university (Unpublished doctoral dissertation). University of British Columbia, Vancouver, BC.

McKay, K. (2014). Report on education in Ontario's colleges. Toronto, ON: OPSEU Communications. Retrieved from http://opseu.org/sites/default/files/ attachments/\%25node\%3Atype/caata_roe_fullreport_en.pdf

Miles, M., Huberman, A. M., \& Saldaña, J. (2014). Qualitative data analysis: A methods sourcebook. Thousand Oaks, CA: Sage Publications.

Morphew, C. (2002). "A rose by any other name”: Which colleges became universities. Review of Higher Education, 25(2), 203-223.

Powles, M., \& Anderson, D. (1996). Participation and access in TAFE: Social service or economic utility? Australian and New Zealand Journal of Vocational Education Research, 4(1), 97-129.

Pusser, B. (2008). The state, the market, and the institutional estate: Revisiting contemporary authority relations in higher education. In J. C. Smart (Ed.), Higher Education: Handbook of Theory and Research (pp. 105-139). Netherlands: Springer.

Pusser, B., Kempner, K., Marginson, S., \& Ordorika, I. (Eds.). (2011). Universities and the public sphere: Knowledge creation and state building in the era of globalization. New York, NY: Routledge.

Quiggin, J. (2010).Zombie economics: How dead ideas still walk among us. Princeton, NJ: Princeton University Press. 
Rampell, C. (2009, March 11). 'Great Recession': A brief etymology [New York Times blog post]. Retrieved from http://economix.blogs.nytimes.com/2009/03/11/greatrecession-a-brief-etymology/?_r=0.

Richards, L. (2009). Handling qualitative data: A practical guide. Thousand Oaks, CA: Sage.

Scott, R. (2014). Institutions and organizations: Ideas, interests, and identities. Los Angeles, CA: Sage Publications.

Seddon, T., Ozga, J., \& Levin, J. S. (2013). Global transitions and teacher professionalism. In Seddon, T., \& Levin, J. S. (Eds.) World yearbook of education 2013: Educators, professionalism and politics: Global transitions, national spaces, and professional projects (pp. 3-24). London, UK: Routledge.

Slaughter, S., \& Leslie, L. (1997). Academic capitalism, politics, policies, and the entrepreneurial university. Baltimore, MD: Johns Hopkins University Press.

Slaughter, S., \& Rhoades, G. (2000). The neo-liberal university. New Labor Forum, Spring/Summer, 73-79.

Slaughter, S., \& Rhoades, G. (2004). Academic capitalism and the new economy: Markets, state, and higher education. Baltimore, MD: Johns Hopkins University Press.

Stromquist, N. P. (2002). Education in a globalized world: The connectivity of economic power, technology, and knowledge. Lanham, MD: Rowman \& Littlefield.

Thornton, P. H., Ocasio, W., \& Lounsbury, M. (2012). The institutional logics perspective: A new approach to culture, structure, and process. New York, NY: Oxford University Press.

\section{Contact Information}

John S. Levin

Graduate School of Education

University of California, Riverside

john.levin@ucr.edu

John S. Levin is a professor of higher education at the University of California, Riverside. Professor Levin is a former British Columbia community college practitioner.

Aida Aliyeva received her Ph.D. in higher education administration and policy at the University of California, Riverside. She also directs institutional research for a private college in southern California. Her research interests include higher education finance, governance, and institutional autonomy.

Laurencia Walker is a doctoral candidate in higher education administration and policy at the University of California, Riverside. She is also a student services manager in the California State University system. Her research interests include students, community colleges, and student services. 